\title{
Chapter 9 \\ Trajectories for a Just Transition of the Fossil Fuel Industry
}

\author{
Sven Teske
}

\begin{abstract}
This section provides historical production data for coal, oil and gas between 1980 and 2015 . The $2.0^{\circ} \mathrm{C}$ and $1.5^{\circ} \mathrm{C}$ scenario lead to specific phase-out pathways for each of the fossil fuel types. Current regional production volumes are compared with future demands. The results provide the input for the employment analysis in the following chapter for the fossil fuel sector. This section discusses the need to shift the current political debate about coal, oil and gas which is focused on security of supply and price security towards an open debate about an orderly withdrawal from coal, oil and gas extraction industries.
\end{abstract}

The implementation of the $2.0^{\circ} \mathrm{C}$ and $1.5^{\circ} \mathrm{C}$ climate mitigation pathways presented here will have a significant impact on the global fossil fuel industry. Although this may appear to be stating the obvious, current climate debates have not yet involved open discussion of the orderly withdrawal from the coal, oil, and gas extraction industries. Instead, the political debate about coal, oil, and gas has focused on the security of supply and price security. However, mitigating climate change is only possible when fossil fuels are phased-out. This section provides an overview of the time-frame of this phase-out under the $2.0^{\circ} \mathrm{C}$ and $1.5^{\circ} \mathrm{C}$ Scenarios compared with the $5.0^{\circ} \mathrm{C}$ pathway.

\subsection{Fossil Energy Resources-The Sky Is the Limit}

An unrelenting increase in fossil fuel extraction conflicts with the finite nature of these resources. At the same time, the global distribution of oil and gas resources does not match the distribution of demand. Therefore, some countries currently rely almost entirely on imported fossil fuels. Therefore, is the relative scarcity of fossil fuels an additional reason an energy transition? The Global Energy Assessment

\footnotetext{
S. Teske $(\square)$

Institute for Sustainable Futures, University of Technology Sydney, Sydney, NSW, Australia

e-mail: sven.teske@uts.edu.au
} 
Table 9.1 Fossil reserves, resources, and additional occurrences

\begin{tabular}{l|l|l|l}
\hline Energy carrier & $\begin{array}{l}\text { Reserves } \\
{[\text { EJ/year }]}\end{array}$ & $\begin{array}{l}\text { Resources } \\
{[\text { EJ/year }]}\end{array}$ & $\begin{array}{l}\text { Demand in 2015 } \\
{[\text { EJ/year }]}\end{array}$ \\
\cline { 1 - 2 } Conventional oil & $4900-7610$ & $4170-6150$ & 41.9 \\
\cline { 1 - 2 } Unconventional oil & $3750-5600$ & $11,280-14,800$ & 33.8 \\
\cline { 1 - 2 } Conventional gas & $5000-7100$ & $7200-8900$ & \\
\hline Unconventional gas & $20,100-67,100$ & $40,200-121,900$ & 16.5 \\
\hline
\end{tabular}

(GEA 2012), an integrated assessment of the global energy system, has published a comprehensive overview of estimated available fossil fuel reserves and resources. Table 9.1 shows the estimates for conventional and unconventional coal, oil, and gas reserves and resources. The distinction between reserves and resources is based on the current technology (exploration and production) and market conditions. The resource data are not cumulative and do not include reserves (GEA 2012).

The assessment shows that there is no shortage of fossil fuels. There might be a shortage of conventional oil and gas, but unconventional resources are still significantly larger than our climate can cope with. Reducing global fossil fuel consumption for reasons of resource scarcity alone is not essential, even though there may be substantial price fluctuations and regional or structural shortages, as we have seen in the past (Teske and Pregger 2015).

\subsection{Coal-Past Production and Future Trajectories Under Three Scenarios}

Global coal production is dominated by China, which in 2017, produced over 3.5 billion tonnes of coal, $45 \%$ of the world volume, followed by India with 716 million tonnes, the USA with 702 million tons, and Australia with 481 million tons. The top 10 producers, in order of annual production, are China, India, USA, Australia, Indonesia, the Russian Federation, South Africa, Germany (mainly lignite), Poland, and Kazakhstan. These countries account for $90 \%$ of the global coal production.

Figure 9.1 shows the historical time series for global coal production. The data are based on the BP Statistical Review 2018 (BP 2018), as are the following overviews of oil and gas. Production volumes have declined in recent years, mainly due to changes in demand in China, but they rose again in 2017.

Under the $5.0{ }^{\circ} \mathrm{C}$ scenario, the required production of thermal coal (excluding coal for non-energy uses, such as steel production) will remain at the 2015 level, with an annual increase of around $1 \%$ per year until 2050. As shown in Fig. 9.2, under the $2.0{ }^{\circ} \mathrm{C}$ Scenario, coal production will decline sharply between 2020 and 2030 at a rate of around $6 \%$ per year. By 2030, the global coal production will be equal to China's annual production in 2017 , at 3.7 billion tons, whereas that volume will be reached in 2025 under the $1.5^{\circ} \mathrm{C}$ Scenario. 


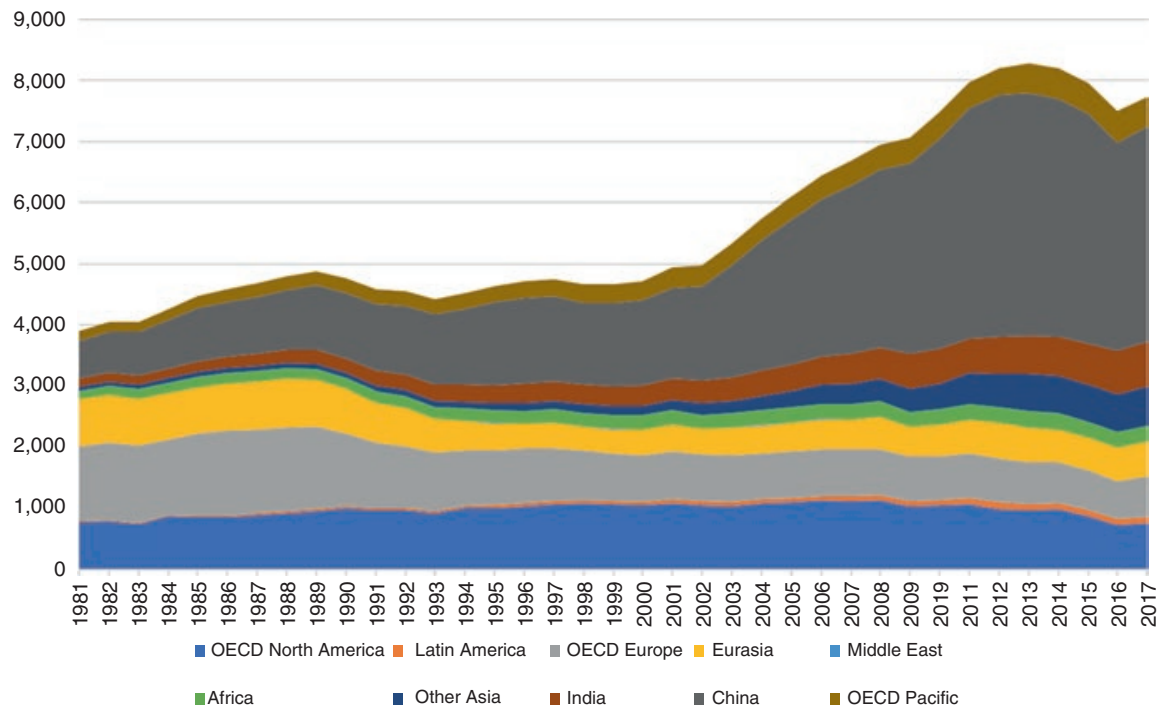

Fig. 9.1 Global coal production in 1981-2017 (BP 2018-Statistical Review)

12,000

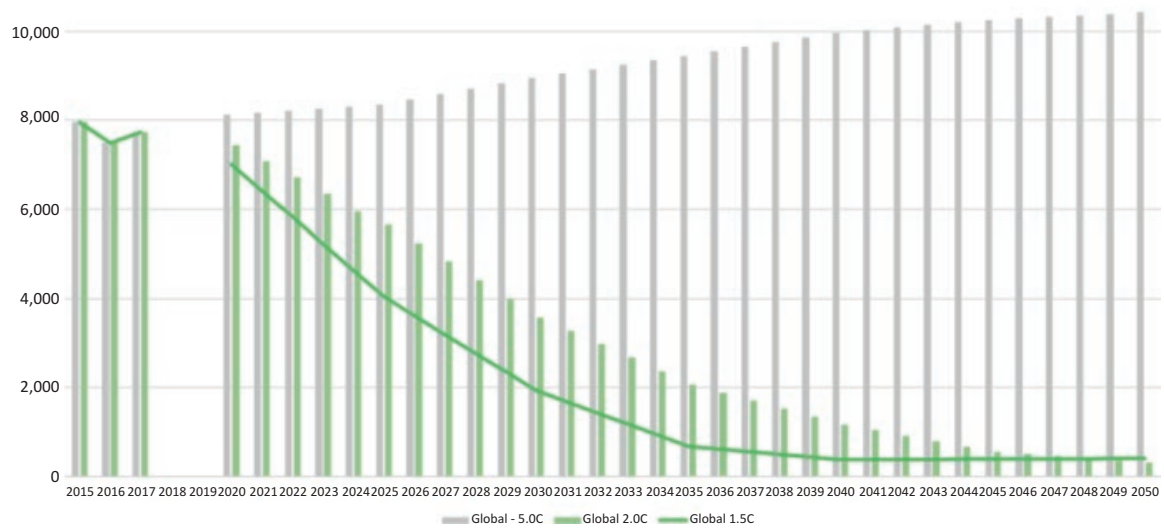

Fig. 9.2 Global coal production until 2050 under the three scenarios 


\subsection{Oil-Past Production and Future Trajectories Under the Three Scenarios}

Oil production almost doubled between 1965 and 1975. After the early 1990s, it grew almost constantly and by 2017 , the production volume was about three times higher than in 1965 and twice as high as in 1985 (Fig. 9.3). Unlike coal, there is no sign of a decline in oil production in response to reduced demand. Oil production is more widely distributed than coal production. Three countries, the USA, Russia, and Saudi Arabia, have global market shares of around 12-14\% each, whereas four countries, Canada, Iran, Iraq, and China, produce around 5\% each. The other oilproducing countries have significantly lower market shares.

Figure 9.4 shows the global oil production levels required by the three calculated scenarios. Oil for non-energy uses, such as the petrochemical industry, is not included in this graph. Again, oil production in the $5.0{ }^{\circ} \mathrm{C}$ Scenario will grow steadily by $1 \%$ until the end of the modelling period in 2050 . Under the $2.0^{\circ} \mathrm{C}$ Scenario, oil production will decline by $5 \%$ per year until 2030 and by $3 \%$ annually until 2025. After 2030, production will decline by around $7 \%$ per year, on average, until oil production for energy is phased-out entirely. The oil production capacity of the USA, Saudi Arabia, and Russia in 2017 would be sufficient to supply the global demand calculated for the $2.0{ }^{\circ} \mathrm{C}$ Scenario in 2035 . The $1.5^{\circ} \mathrm{C}$ Scenario will cut the required production volumes in half by 2030 , reducing them further to the equivalent of the production volume of just one of the three largest oil producers (the USA, Saudi Arabia, or Russia) by 2040.

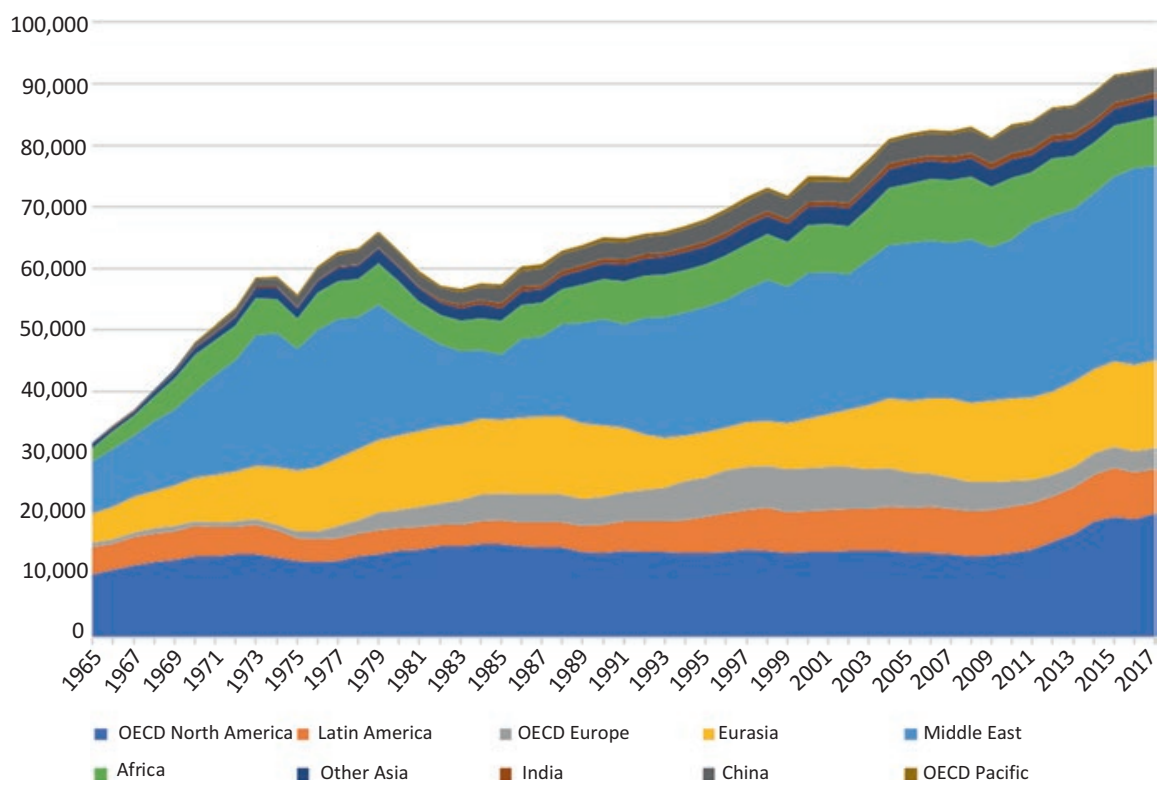

Fig. 9.3 Global oil production in 1965-2017 (BP 2018-Statistical Review) 


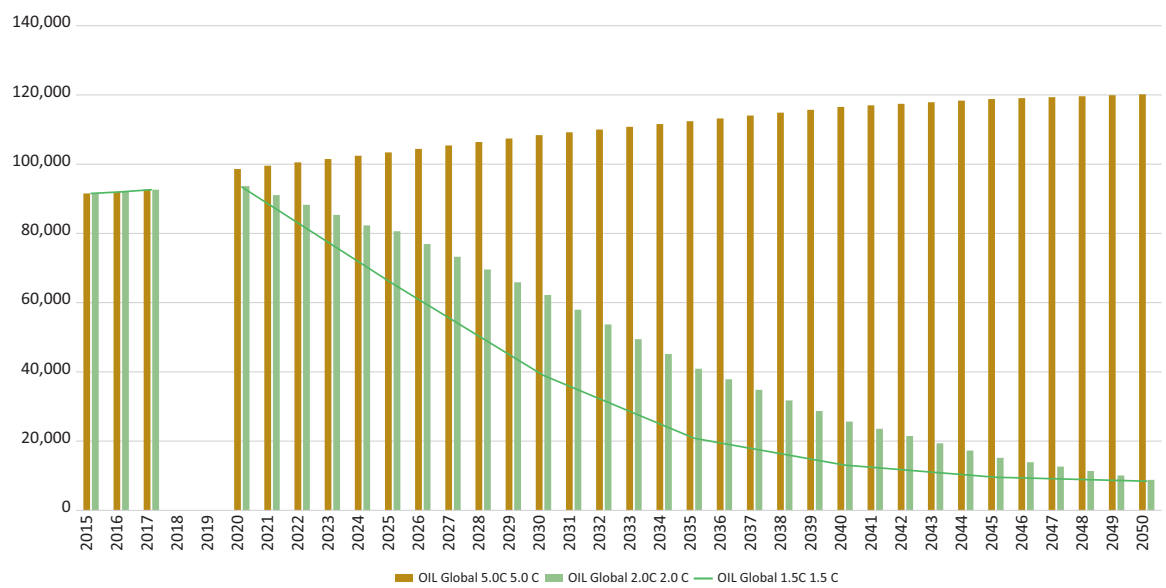

Fig. 9.4 Global oil production until 2050 under the three scenarios

\subsection{Gas-Past Production and Future Trajectories Under the Three Scenarios}

Gas production has grown steadily over the past four decades, leading to an overall production of 3500 billion cubic meters-3.5 times higher than in 1970. The production of natural gas is even more widely distributed than oil production. According to 2017 figures, by far the largest producers are the USA, with $20 \%$ of the global volume, and Russia with $17 \%$. Four countries have market share of around 5\% each: Canada (4.8\%), Iran (6.1\%), Qatar (4.8\%), and China (4.1\%). The remaining $43 \%$ of global gas production is distributed over 42 countries (Fig. 9.5).

In the $5.0^{\circ} \mathrm{C}$ Scenario, gas production will increase steadily by $2 \%$ a year for the next two decades, leading to an overall production increase of about $50 \%$ by 2050 . Compared with coal and oil, the gas phase-out will be significantly slower in the $2.0^{\circ} \mathrm{C}$ and $1.5^{\circ} \mathrm{C}$ Scenarios. Furthermore, these scenarios assume that infrastructure, such as gas pipelines and power plants, will be used after this phase-out for hydrogen and/or renewable methane produced with electricity from renewable sources (see Chap. 5, Sect 5.2). Under the $2.0^{\circ} \mathrm{C}$ Scenario, gas production will only decrease by $0.2 \%$ per year until 2025 , then by $1 \%$ until 2030 , and on average by $4 \%$ annually until 2040. This represents a rather slow phase-out and will allow the gas industry to gradually transfer to hydrogen. The phase-out under the $1.5^{\circ} \mathrm{C}$ Scenario will be equally slow, and a 4\%/year reduction will occur after 2025 (Fig. 9.6). 


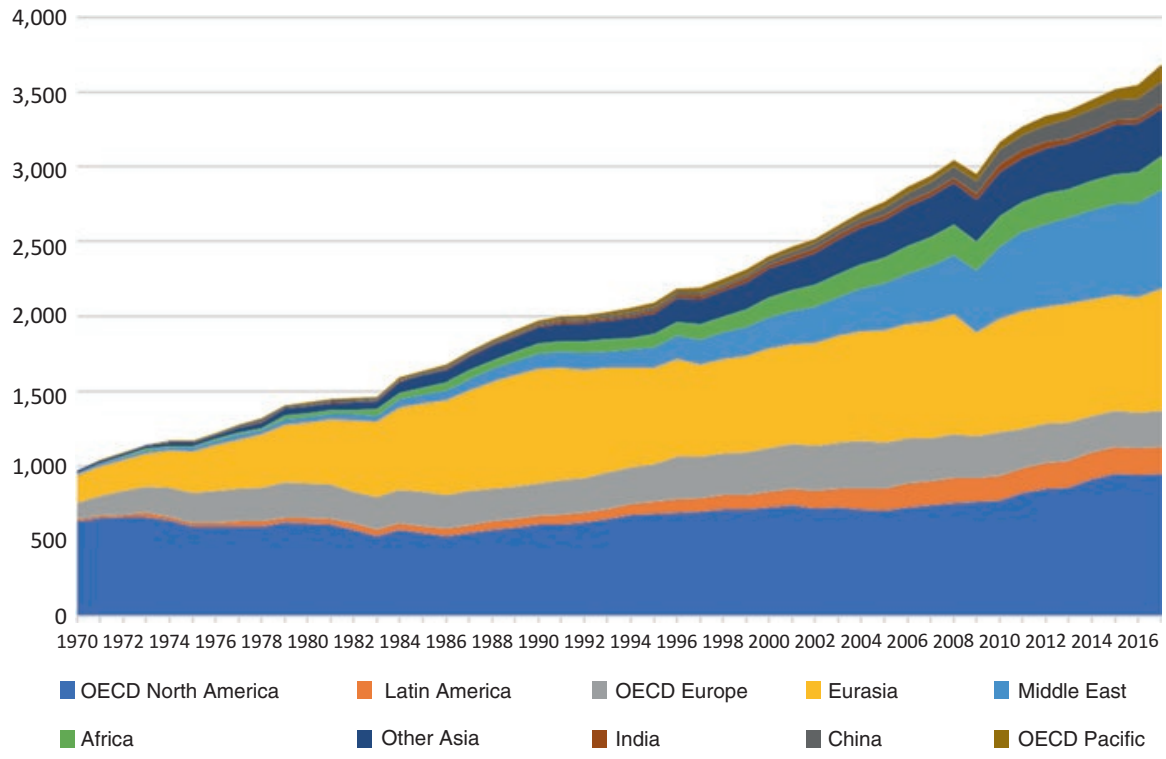

Fig. 9.5 Global gas production in 1970-2017 (BP 2018-Statistical Review)

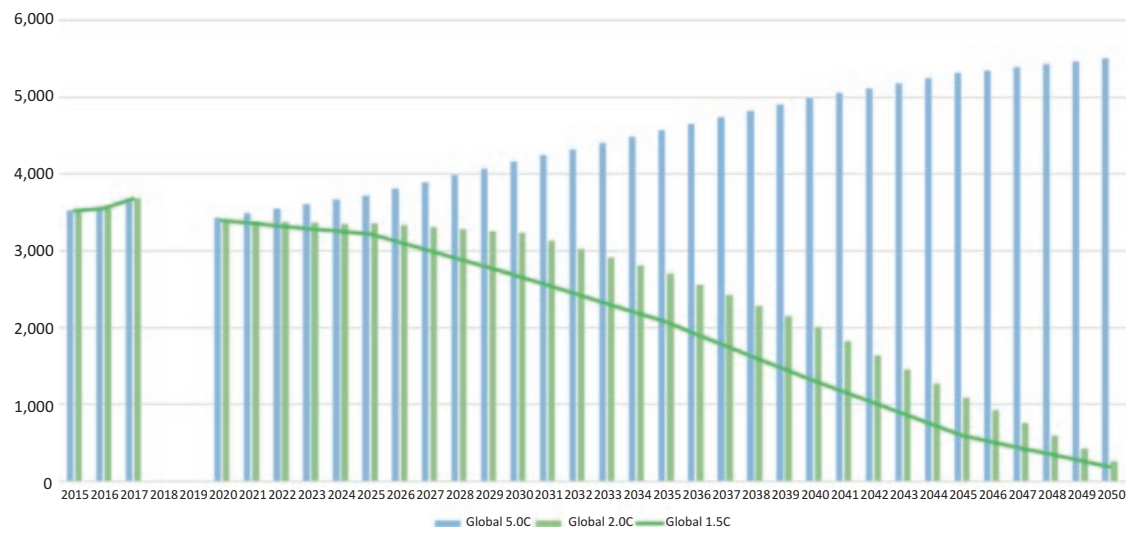

Fig. 9.6 Global gas production until 2050 under the three scenarios 


\subsection{Overview: Required Fossil Fuel Resources Under the $5.0{ }^{\circ} \mathrm{C}, 2.0^{\circ} \mathrm{C}$, and $1.5^{\circ} \mathrm{C}$ Trajectories}

In summary, the global fossil fuel extraction industry must reduce production at a rate of $2 \%$ per annum under the $2.0^{\circ} \mathrm{C}$ Scenario and $3 \%$ per annum under the $1.5^{\circ} \mathrm{C}$ Scenario. A constant reduction in production seems unlikely if no international measures are taken to organize the economic and social transitions in the producing countries, and for the communities and workers involved. The idea of a 'just transition' is well documented in the international literature. According to the International Labour Organization (ILO 2015), the concept was first mentioned in the 1990s, when North American unions began developing the concept of just transition.

Initially, trade unionists understood 'just transition' to be a program of support for workers who lost their jobs due to environmental protection policies. Since then, several UNFCCC Climate Conferences have referred to the 'just transition' concept. The Paris Climate Agreement 2015, during the 21st session of the Conference of the Parties (COP 21) "decided to continue and improve the forum on the impact of the implementation of response measures (hereinafter referred to as the improved forum), and adopted the work programme, comprising two areas: (1) economic diversification and transformation; and (2) just transition of the workforce, and the creation of decent work and quality jobs" (UNFCCC-JT 2016).

Table 9.2 provides possible trajectories for global coal, oil, and gas production, consistent with the Paris Agreement targets. These trajectories are the results of the $2.0^{\circ} \mathrm{C}$ and $1.5^{\circ} \mathrm{C}$ Scenarios, documented in detail over the previous six chapters of this book. Chapter 10 uses these trajectories to calculate possible employment effects, both in terms of job losses in the fossil fuel industry, job gains in the renewable energy industry, and options for transitioning the gas industry towards a renewably produced hydrogen industry. 
Table 9.2 Summary—coal, oil, and gas trajectories for a just transition under the $5.0{ }^{\circ} \mathrm{C}, 2.0^{\circ} \mathrm{C}$, and $1.5^{\circ} \mathrm{C}$ Scenarios

\begin{tabular}{|c|c|c|c|c|c|c|c|c|}
\hline & 2015 & 2020 & 2025 & 2030 & 2035 & 2040 & 2045 & 2050 \\
\hline \multicolumn{9}{|c|}{$5.0^{\circ} \mathrm{C}$ : Primary energy [PJ/a] } \\
\hline Coal & 140,895 & 147,324 & 153,529 & 167,795 & 179,666 & 191,078 & 196,692 & 200,680 \\
\hline Lignite & 19,835 & 18,836 & 18,550 & 18,573 & 18,597 & 19,028 & 19,546 & 19,562 \\
\hline Natural gas & 123,673 & 133,732 & 145,075 & 162,132 & 178,213 & 194,467 & 207,273 & 214,702 \\
\hline Crude oil & 166,465 & 173,082 & 181,520 & 190,294 & 197,300 & 204,563 & 208,561 & 210,970 \\
\hline \multicolumn{9}{|l|}{$5.0^{\circ} \mathrm{C}$ production units } \\
\hline $\begin{array}{l}\text { Coal [million tons per } \\
\text { year] }\end{array}$ & 5871 & 6138 & 6397 & 6991 & 7486 & 7962 & 8196 & 8362 \\
\hline $\begin{array}{l}\text { Lignite [million tons } \\
\text { per year] }\end{array}$ & 2088 & 1983 & 1953 & 1955 & 1958 & 2003 & 2058 & 2059 \\
\hline $\begin{array}{l}\text { Natural gas [billion } \\
\text { cubic meters] }\end{array}$ & 3171 & 3429 & 3720 & 4157 & 4570 & 4986 & 5315 & 5505 \\
\hline $\begin{array}{l}\text { Oil [thousand barrels } \\
\text { per day] }\end{array}$ & 94,836 & 98,606 & 103,414 & 108,412 & 112,403 & 116,541 & 118,819 & 120,191 \\
\hline \multicolumn{9}{|c|}{$2.0^{\circ} \mathrm{C}$ - primary energy $[\mathrm{PJ} / \mathrm{a}]$} \\
\hline Coal & 140,624 & 136,111 & 114,647 & 77,766 & 45,445 & 25,594 & 12,480 & 7568 \\
\hline Lignite & 19,835 & 16,779 & 8333 & 3203 & 1630 & 912 & 288 & 0 \\
\hline Natural gas & 123,770 & 132,209 & 130,797 & 126,054 & 105,321 & 78,390 & 42,535 & 9949 \\
\hline Crude oil & 166,472 & 164,438 & 141,523 & 109,213 & 71,812 & 45,013 & 26,649 & 15,461 \\
\hline \multicolumn{9}{|l|}{$2.0^{\circ} \mathrm{C}$-production units } \\
\hline $\begin{array}{l}\text { Coal [million tons per } \\
\text { year] }\end{array}$ & 5859 & 5671 & 4777 & 3240 & 1894 & 1066 & 520 & 315 \\
\hline $\begin{array}{l}\text { Lignite [million tons } \\
\text { per year] }\end{array}$ & 2088 & 1766 & 877 & 337 & 172 & 96 & 30 & 0 \\
\hline $\begin{array}{l}\text { Natural gas [billion } \\
\text { cubic meters] }\end{array}$ & 3174 & 3390 & 3354 & 3232 & 2701 & 2010 & 1091 & 255 \\
\hline $\begin{array}{l}\text { Oil [thousand barrels } \\
\text { per day] }\end{array}$ & 94,840 & 93,682 & 80,627 & 62,219 & 40,912 & 25,644 & 15,182 & 8808 \\
\hline \multicolumn{9}{|c|}{$1.5^{\circ} \mathrm{C}$ - primary energy $[\mathrm{PJ} / \mathrm{a}]$} \\
\hline Coal & 141,275 & 125,431 & 84,267 & 41,360 & 14,243 & 9134 & 9363 & 9759 \\
\hline Lignite & 19,835 & 16,956 & 5006 & 2056 & 777 & 0 & 0 & 0 \\
\hline Natural gas & 123,426 & 132,241 & 125,494 & 104,349 & 80,940 & 50,883 & 23,202 & 7315 \\
\hline Crude oil & 166,472 & 163,957 & 114,986 & 68,449 & 36,541 & 22,923 & 16,772 & 14,794 \\
\hline \multicolumn{9}{|l|}{$1.5^{\circ} \mathrm{C}$ production units } \\
\hline $\begin{array}{l}\text { Coal [million tons per } \\
\text { year] }\end{array}$ & 5886 & 5226 & 3511 & 1723 & 593 & 381 & 390 & 407 \\
\hline $\begin{array}{l}\text { Lignite [million tons } \\
\text { per year] }\end{array}$ & 2088 & 1785 & 527 & 216 & 82 & 0 & 0 & 0 \\
\hline $\begin{array}{l}\text { Natural gas [billion } \\
\text { cubic meters] }\end{array}$ & 3165 & 3391 & 3218 & 2676 & 2075 & 1305 & 595 & 188 \\
\hline $\begin{array}{l}\text { Oil [thousand barrels } \\
\text { per day] }\end{array}$ & 94,840 & 93,408 & 65,509 & 38,996 & 20,818 & 13,059 & 9555 & 8428 \\
\hline
\end{tabular}




\section{References}

BP (2018), British Petrol, Statistical review, website with statistical data for download, downloaded in September 2018, https://www.bp.com/en/global/corporate/energy-economics/statistical-review-of-world-energy/downloads.html

GEA (2012): Global Energy Assessment - Toward a Sustainable Future, Cambridge University Press, Cambridge, UK and New York, NY, USA and the International Institute for Applied Systems Analysis, Laxenburg, Austria; www.globalenergyassessment.org

ILO (2015), International Labour Organization, Just Transition - A report for the OECD, May 2017, Just Transition Centre, www.ituc-csi.org/just-transition-centre

Teske, Pregger (2015), Teske, S, Pregger, T., Naegler, T., Simon, S., Energy [R]evolution A sustainable World Energy Outlook 2015, Greenpeace International with the German Aerospace Centre (DLR), Institute of Engineering Thermodynamics, System Analysis and Technology Assessment, Stuttgart, Germany https://www.scribd.com/document/333565532/ Energy-Revolution-2015-Full

UNFCCC-JT (2016) Just Transition of the Workforce, and the Creation of Decent Work and Quality Jobs - Technical paper, United Nations - Framework Convention on Climate Change (UNFCCC) $20 \mathrm{https://unfccc.int/sites/default/files/resource/Just \% 20transition.pdf}$

Open Access This chapter is licensed under the terms of the Creative Commons Attribution 4.0 International License (http://creativecommons.org/licenses/by/4.0/), which permits use, sharing, adaptation, distribution and reproduction in any medium or format, as long as you give appropriate credit to the original author(s) and the source, provide a link to the Creative Commons licence and indicate if changes were made.

The images or other third party material in this chapter are included in the chapter's Creative Commons licence, unless indicated otherwise in a credit line to the material. If material is not included in the chapter's Creative Commons licence and your intended use is not permitted by statutory regulation or exceeds the permitted use, you will need to obtain permission directly from the copyright holder.

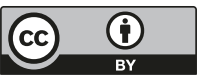

